\begin{tabular}{|l|l|l|}
\hline \multicolumn{2}{|c|}{ PublisherInfo } \\
\hline \hline PublisherName & $:$ & BioMed Central \\
\hline \hline PublisherLocation & $:$ & London \\
\hline \hline PublisherImprintName & $:$ & BioMed Central \\
\hline \hline
\end{tabular}

\title{
Notch-ing up cancer genes
}

\begin{tabular}{|l|l|l||}
\hline \multicolumn{2}{|c|}{ ArticleInfo } \\
\hline \hline ArticleID & $:$ & 4703 \\
\hline \hline ArticleDOI & $:$ & $10.1186 /$ gb-spotlight-20030219-01 \\
\hline \hline ArticleCitationID & $:$ & spotlight-20030219-01 \\
\hline \hline ArticleSequenceNumber & $:$ & 55 \\
\hline \hline ArticleCategory & $:$ & Research news \\
\hline ArticleFirstPage & $:$ & 1 \\
\hline \hline ArticleLastPage & $:$ & 2 \\
\hline \hline & & RegistrationDate : 2003-2-19 \\
\hline ArticleHistory & $:$ & OnlineDate \\
\hline \hline ArticleCopyright & $:$ & BioMed Central Ltd2003 \\
\hline \hline ArticleGrants & $:$ & \\
\hline \hline ArticleContext & $:$ & 130594411 \\
\hline \hline
\end{tabular}




\section{Jonathan B Weitzman}

Email: jonathanweitzman@hotmail.com

Notch receptor signalling has been implicated in cell-fate decisions and differentiation in a variety of tissues. In an Advanced Online Publication in Nature Genetics Nicolas et al. define a tumour suppressor function for the mouse Notch1 gene (Nature Genetics, 18 February 2003, doi:10.1038/ng1099). As Notchl is essential for embryonic development, they used a tissue-specific inducible gene-targeting approach to specifically delete the Notch1 gene in the skin. Notch1 ablation led to epidermal hyperproliferation and the development of basal cell carcinoma-like tumors. This was unexpected as active Notch signalling has been shown to cause tumors in other tissues. The Notchl-less mice were also susceptible to chemically induced carcinogenesis. Tumors lacking Notch1 were associated with decreased levels of the cyclin dependent kinase inhibitor $\mathrm{p} 21^{\mathrm{Cip} 1}$ and elevated levels of the transcription factor Gli2 and components of the $\beta$-catenin/Wnt signaling pathway.

\section{References}

1. Notch signaling: cell fate control and signal integration in development.

2. Nature Genetics, [http://www.nature.com/naturegenetics] 